\title{
Coral disease in the Indian Ocean: taxonomic susceptibility, spatial distribution and the role of host density on the prevalence of white syndrome
}

\author{
Jean-Paul A. Hobbs ${ }^{1, *}$, Ashley J. Frisch ${ }^{2}$ \\ ${ }^{1}$ ARC Centre of Excellence for Coral Reef Studies, School of Marine and Tropical Biology, James Cook University, \\ Townsville, Queensland 4811, Australia \\ ${ }^{2}$ Ecosystem Conservation and Sustainable Use Group, Great Barrier Reef Marine Park Authority, Townsville, \\ Queensland 4810, Australia
}

\begin{abstract}
Coral diseases, such as white diseases and white syndrome (WS), have caused widespread damage to coral reefs throughout the Caribbean and are increasing in prevalence on Pacific Ocean reefs. The current study confirms that WS is also present on coral reefs in the Indian Ocean and tests whether patterns in taxonomic susceptibility and spatial variability conform to patterns of WS reported in the Pacific Ocean. Underwater surveys at 19 sites around Christmas and Cocos Islands revealed that WS primarily affects Acropora plate corals (A. clathrata, A. cytherea and A. hyacinthus), and prevalence of WS varied significantly across all 3 spatial scales investigated (island, exposure and depth). Approximately 13.0\% (range $=0$ to $43 \%$ per site) of plate corals at Christmas Island sites exhibited WS compared to $<1 \%$ at the Cocos Islands. At Christmas Island, WS prevalence was greater in shallow $(31.5 \%)$ than in deeper water $(6.7 \%)$ and greatest on the northern (leeward) side of the island (31.5\%) compared to the more exposed coastlines (0 to $1.5 \%$ ). Importantly, the spatial distribution of WS was positively correlated with host density, but not with hard coral cover, suggesting a role of host density in WS outbreaks. Overall the present study has established that WS is impacting remote, near-pristine reefs in the Indian Ocean. However, the highly variable spatial distribution of WS illustrates that patterns in disease prevalence, and the subsequent impact on coral reefs, can be location- or region-specific.
\end{abstract}

KEY WORDS: Coral disease $\cdot$ White syndrome $\cdot$ Acropora $\cdot$ Christmas Island $\cdot$ Cocos (Keeling) Islands Resale or republication not permitted without written consent of the publisher

\section{INTRODUCTION}

Marine diseases are increasing worldwide and pose a serious threat to the future of coral reefs (Harvell et al. 1999, Sutherland et al. 2004). Some coral reefs have already been devastated by disease (Richardson 1998, Harvell et al. 1999, Aronson \& Precht 2001), and outbreaks are predicted to increase in the future (Willis et al. 2004, Bruno et al. 2007). Establishing the prevalence and distribution of coral diseases is considered a priority (Harvell et al. 2002), because it helps to identify the origins, reservoirs, modes of transmission and potential causes of disease outbreaks (Willis et al.
2004). However, the prevalence and distribution of coral diseases has not yet been determined for many parts of the world.

In the past, coral diseases were mainly studied in the Caribbean region, which is considered a global hotspot of disease (Harvell et al. 1999, Green \& Bruckner 2000). However, an increasing number of studies are revealing that coral diseases occur across a range of Pacific Ocean locations and the prevalence of some diseases has increased as much as 150-fold in 5 yr (Sutherland et al. 2004, Willis et al. 2004, Bruno \& Selig 2007, Bruno et al. 2007). Known differences between the Caribbean and Pacific Ocean, with respect to disease ecology, 
aetiology and epidemiology (e.g. Antonius 1985, Kuta \& Richardson 1996, 2002, Bruckner \& Bruckner 1997, Bruckner et al. 1997, Willis et al. 2004), have led to the conclusion that coral diseases must be examined on a region-by-region basis (Willis et al. 2004).

Some coral disease outbreaks in the Caribbean and Pacific Ocean have been linked to changes in environmental conditions (e.g. increased water temperature; Patterson et al. 2002, Bruno et al. 2007). The same climatic events that increased sea temperatures in the Caribbean and Pacific Ocean have affected, often with greater severity, coral reefs in the Indian Ocean (Goreau et al. 2000, Graham et al. 2006, Smith et al. 2008). However, the impacts of coral disease on Indian Ocean reef communities are largely unknown. Although coral diseases have been studied in the adjoining Red Sea (Antonius 1985) and Arabian Gulf (Riegl 2002), there have only been preliminary reports of disease in the Indian Ocean (Coles 1994, Coles \& Seapy 1998, Antonius \& Afonso-Carillo 2001, Ben-Haim \& Rosenberg 2002, Ravindran \& Raghukumar 2002) and little is known of the prevalence, distribution and impact of these and other unreported diseases on Indian Ocean coral reefs (McClanahan et al. 2004).

The most destructive and widespread group of coral diseases are those categorised as white diseases and white syndrome (WS). These diseases have caused coral mortality on reefs in the Caribbean, Philippines, Great Barrier Reef and Red Sea (Antonius 1985, Richardson et al. 1998, Harvell et al. 1999, Green \& Bruckner 2000, Aronson \& Precht 2001, Willis et al. 2004, Bruno et al. 2007, Miller \& Williams 2007). The prevalence of white diseases and WS can vary between regions (Willis et al. 2004), with distance from shore (Willis et al. 2004), and between sides of an island (Dalton \& Smith 2006, Miller \& Williams 2007). WS is most commonly reported from shallow waters (3 to $14 \mathrm{~m}$ ) (Willis et al. 2004, Dalton \& Smith 2006), but it is not known if prevalence varies with depth. Although WS impacts on a range of coral taxa (Antonius 1985, Sutherland et al. 2004, Willis et al. 2004), acroporid species tend to be most susceptible (Green \& Bruckner 2000, Willis et al. 2004, Bruno et al. 2007). Outbreaks of WS in the Pacific Ocean have also been linked to high densities of live coral cover $(>50 \%$; Bruno et al. 2007). However, the potentially independent effects of high host density and high live coral cover have not been separated.

Given that coral diseases have caused widespread destruction to Caribbean reefs (Richardson 1998, Harvell et al. 1999, Aronson \& Precht 2001), and are increasing rapidly in prevalence in the Pacific Ocean (Willis et al. 2004), it is imperative to assess the impact of coral disease on reefs in the Indian Ocean. In the present study we document the first occurrence of WS in the Indian Ocean and test whether patterns of disease prevalence conform to those patterns found for white diseases in the Caribbean and for WS in the Pacific Ocean. Hence, the aims of the present study were to (1) test whether WS on coral reefs in the Indian Ocean mainly affects Acropora species, (2) determine the prevalence and distribution of WS across different spatial scales (island, exposure and depth), and (3) determine if WS prevalence is linked to high host density and/or high live coral cover.

\section{MATERIALS AND METHODS}

Study site. Christmas $\left(10^{\circ} 30^{\prime} \mathrm{S}, 105^{\circ} 40^{\prime} \mathrm{E}\right)$ and Cocos (Keeling) Islands $\left(12^{\circ} 12^{\prime} \mathrm{S}, 9^{\circ} 54^{\prime} \mathrm{E}\right)$ are isolated islands in the eastern Indian Ocean located approximately 350 and $1000 \mathrm{~km}$, respectively, southwest of Java, Indonesia. The Cocos Islands comprise a typical coral atoll with 26 low-lying sandy islands situated on the perimeter of a central lagoon. Christmas Island is a single high island about $900 \mathrm{~km}$ east of the Cocos Islands. Totals of 88 and 99 species of scleractinian corals have been recorded from Christmas and Cocos Islands, respectively (Done \& Marsh 1988, Veron 1994). The human populations of both Christmas (<2000 people) and Cocos Islands (<1000 people) are very small, and there has been little anthropogenic impact on the reefs. Therefore, these islands provide the opportunity to examine the prevalence and distribution of WS in relatively pristine reef systems in the Indian Ocean.

Lesion description. WS was first observed at Christmas and Cocos Islands in February and March 2008. The lesions observed on the corals were very similar to those detailed by Work \& Aeby (2006) for 'Acropora white syndrome', and, to maintain consistency in lesion descriptions, we use their terminology. The lesions comprised a large, diffuse, band of tissue loss revealing a bare, white, intact skeleton (Fig. 1). The band was variable in width (1 to $70 \mathrm{~cm}$ ) (Fig. 1) and had living tissue on one side and intact, brown (covered with filamentous algae) skeleton on the other side. The lesions were mild to severe in spatial extent, subacute (possibly chronic), and tissue loss involved the coenosarc and polyps (see Work \& Aeby 2006 for definitions). This description also fits that of 'acroporid white syndrome' found on the Great Barrier Reef (Roff et al. $2006,2008)$. Due to the highly variable width of the white band and unknown identity of the causative agent(s) infecting the corals, it was not possible to diagnose a specific white disease (Richardson 1998). Instead the term 'white syndrome' was used to include all corals exhibiting the above-mentioned white lesions (Willis et al. 2004), and the terms 'Acropora' or 'acroporid' were not used because the lesions were not entirely restricted to this group. 

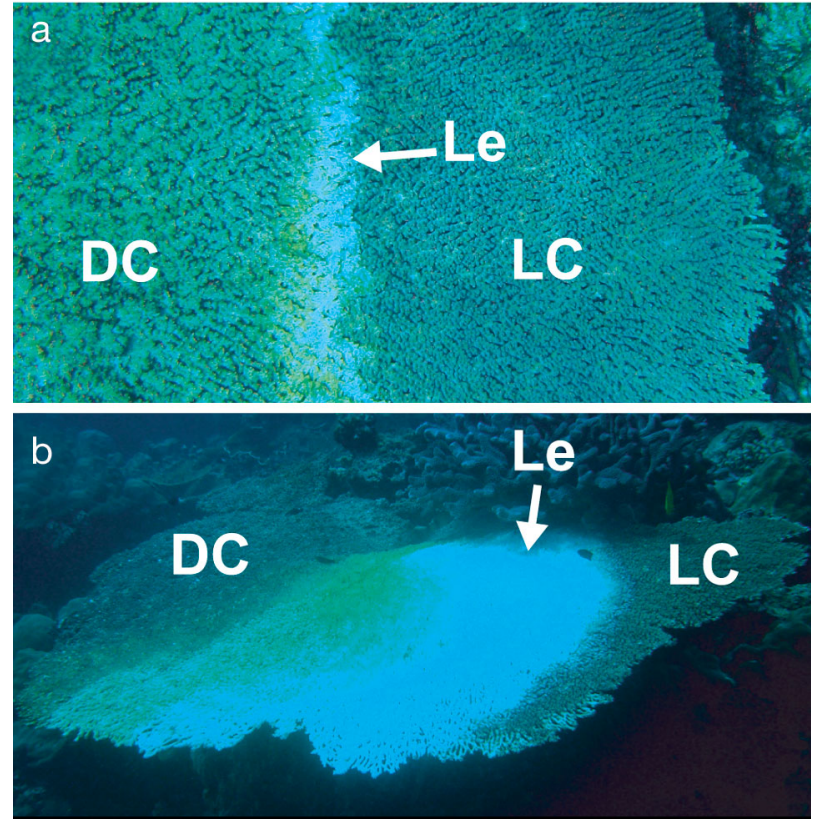

Fig. 1. Acropora plate corals. Corals with white syndrome at Christmas Island. The white band is the lesion area (Le) and represents recent tissue death, with live coral (LC) to the right and dead coral (DC), colonised by filamentous algae, to the left. Note the variable width of the white band: (a) 3 to $8 \mathrm{~cm}$ and (b) $60 \mathrm{~cm}$

White patches on corals can also be caused by predators of corals (e.g. Drupella spp. and Acanthaster plancii), which may potentially act as vectors. Therefore, all surfaces of colonies with white lesions (defined above) were checked for the presence of coral predators. In addition, corals with WS were examined for the presence of black band disease as a secondary infection (Antonius 1985).

Survey design. The distribution and prevalence of WS was investigated through underwater surveys at 10 sites at Christmas Island and 9 sites at the Cocos Islands from February to April 2008. Surveys were conducted whilst SCUBA diving at a depth of $5 \mathrm{~m}$ and consisted of 3 randomly placed replicate $30 \times 5 \mathrm{~m}$ belt transects per site. We recorded the identity and morphology of diseased corals within, and immediately next to, the belt transects. Coral morphologies included: branching, corymbose, plate (i.e. tabular), foliose, massive, columnar, encrusting and free-living (fungids) (Veron 1986). The number of diseased and non-diseased Acropora plate corals (the group most susceptible to WS) within each transect was compared across different spatial scales.

Variation in WS prevalence in Acropora plate corals across different wave-exposure regimes was examined using randomly selected sites on the north $(\mathrm{n}=4)$, south $(n=2)$, east $(n=2)$ and west $(n=2)$ coasts of Christmas Is- land. Due to the prevailing south-easterly trade winds and southerly swell, the south coast is the most exposed coast, while the east and west coasts experience moderate exposure, and the north coast is relatively sheltered. A lack of WS at the Cocos Islands prevented similar analyses at this location. Variation in WS prevalence between depths was examined by repeating surveys at $20 \mathrm{~m}$ depth at the 4 north coast sites on Christmas Island. These sites were chosen because WS was relatively common there and thus allowed for effective statistical comparisons between depths (5 versus $20 \mathrm{~m}$ ).

The relationships between WS prevalence in Acropora plate corals and host density and live coral cover was examined using the total number of infected and non-infected plate corals encountered in the belt transects and the percent cover of plate corals and scleractinian corals recorded in quadrats. Percent coral cover was estimated using 2 replicate $2 \times 2 \mathrm{~m}$ benthic quadrats placed randomly on the substrate within each transect (equalling 6 replicate quadrats per site). Within each quadrat, the percent cover was estimated for each of the following categories: live hard coral (Scleractinia), soft coral, sponge, calcareous coralline algae, filamentous algae, anemones, sand, rubble, dead hard coral and other (zooanthids, gorgonians, seagrass and macro-algae). The live hard coral category was further divided into the 8 morphological categories described above. Data from surveys at $5 \mathrm{~m}$ depth at both island locations were used in the analyses.

Statistical analyses. Statistical comparisons of the prevalence of WS between islands, sides of an island and depths were each made using 1-way analysis of variance (ANOVA; Zar 1999). Non-parametric analyses (Mann-Whitney $U$-test and Kruskal-Wallis test) were used when heteroscedastic data were encountered (Zar 1999). Because the assumptions of a parametric test could not be met (due to heteroscedastic and non-normally distributed data), a Spearman's rank correlation was used to examine if WS prevalence was related to percent coral cover and host density. Statistical analyses were performed using SPSS computer software, and a significant difference was defined as $\mathrm{p}<0.05$. All data are presented as arithmetic means \pm standard error (SE) unless otherwise stated.

\section{RESULTS}

\section{Taxonomic susceptibility}

Only 5 coral colonies exhibited WS at the Cocos Islands and all were Acropora hyacinthus plates. Almost all of the 184 corals that had WS at Christmas Island were Acropora species, the only exception being 1 pocilloporid colony. The majority (96.7\%) of 
the 184 corals with WS were of plate morphology and included A. clathrata, A. cytherea and A. hyacinthus. The prevalence of WS in different coral morphologies was not related to the proportional representation of those coral morphologies in the benthic community. WS was most prevalent in plate corals, yet this morphology only had the fifth greatest abundance in the hard coral community, representing just $5.7 \%( \pm 1.6)$ of benthic cover at Christmas Island and $1.4 \%( \pm 0.6)$ at the Cocos Islands. The morphologies exhibiting the highest coral cover at Christmas Island (9.8 to $11.4 \%$ ) were branching (Acropora and Pocillopora spp.), encrusting (mainly Montipora spp.) and massive (mainly Porites spp.). WS was not observed on any of these corals, except for 2 colonies of branching Acropora (representing $1 \%$ of all corals observed with WS).

All colonies exhibiting WS were closely examined, and no evidence was found to suggest that coral predators (e.g. Drupella spp. and Acanthaster plancii) were involved in tissue death. Black band disease was not present on any colonies that had WS. Several colonies exhibiting WS were observed over a 4 wk period, and the white band progressed across the colony, indicating that tissue death was most likely due to disease and not predation by snails or starfish.

\section{Island patterns}

Spatial patterns of WS prevalence were examined for Acropora plate corals because this was the group most affected by WS. The mean prevalence of WS in Acropora plate corals per site was approximately 15 times higher at Christmas Island $(13.0 \pm 5.5 \%)$ than at the Cocos Islands $(0.85 \pm 0.63 \%)$. This difference was not statistically significant (Mann-Whitney $U, Z=$ $1.82, \mathrm{p}=0.069$ ) because of the limited statistical power due to the absence of WS at 4 of the 10 sites at Christmas Island and 7 of the 9 sites at the Cocos Islands. Reanalysing the data at the transect level revealed that the prevalence of WS in Acropora plate corals per transect was significantly higher at Christmas Island than at Cocos Islands (Mann-Whitney $U, Z=2.96, \mathrm{p}=0.003$; Fig. 2). Also, the proportion of transects containing corals with WS was significantly higher at Christmas Island (12 of the 30 transects) compared at the Cocos Islands ( 2 of the 27 transects) ( $\chi^{2}$ test with Yates' correction, $\left.\chi^{2}=6.48, \mathrm{p}=0.01\right)$. The mean density of Acropora plate corals per $150 \mathrm{~m}^{2}$ at Christmas Island sites $(9.0 \pm 1.8)$ was twice the mean density recorded at sites at the Cocos Islands (4.5 \pm 1.4$)$ (Fig. 2). This difference was not statistically significant when analysed at the site level (ANOVA, $F_{1,17}=3.77, \mathrm{p}=0.069$ ); however, analysis at the transect level revealed a significance difference (ANOVA, $F_{1,55}=9.57, \mathrm{p}=0.003$ ).

\section{Exposure patterns}

Due to the scarcity of WS at the Cocos Islands, the relationship between exposure and WS abundance was only examined for Christmas Island. The prevalence of WS in Acropora plate corals differed significantly around the 4 sides of Christmas Island (ANOVA, $F_{3,6}=9.76, \mathrm{p}=0.01$ ). The north (leeward) coast contained the greatest percentage of plate corals with WS $(31.5 \pm 6.2 \%)$, which was $>20$ times higher than the prevalence of WS encountered on the other 3 coasts (0 to $1.5 \%$ ) (Fig. 3). The mean density of Acropora plate corals was similar on the eastern, western and northern coasts (9.0 to 12.7 colonies per $150 \mathrm{~m}^{2}$ ) and lower on the southern coast (4.5 colonies per $150 \mathrm{~m}^{2}$ ) (Kruskal-Wallis test, $H=1.83$, p =0.61; Fig. 3).

\section{Coral cover and host density}

Analyses of data from the $5 \mathrm{~m}$ depth surveys undertaken at the 19 survey sites across Christmas and Cocos Islands revealed that the prevalence of WS in Acropora plate corals corresponded with high host densities, but not with high hard coral cover. The percentage of Acropora plate corals with WS was positively correlated with both the percent cover of Acropora plate corals $\left(r_{\mathrm{s}}=0.49, \mathrm{p}=0.03\right.$; Fig. $\left.4 \mathrm{a}\right)$ and the number of Acropora plate coral colonies $\left(r_{\mathrm{s}}=0.59\right.$, $\mathrm{p}=0.007$; Fig. 4b). The prevalence of WS was greatest on the north coast of Christmas Island, and these sites tended to have high densities of Acropora plate corals. No relationship was detected between the prevalence of WS in Acropora plate corals and the percentage cover of live hard corals $\left(r_{\mathrm{s}}=0.33, \mathrm{p}=0.18\right)$.

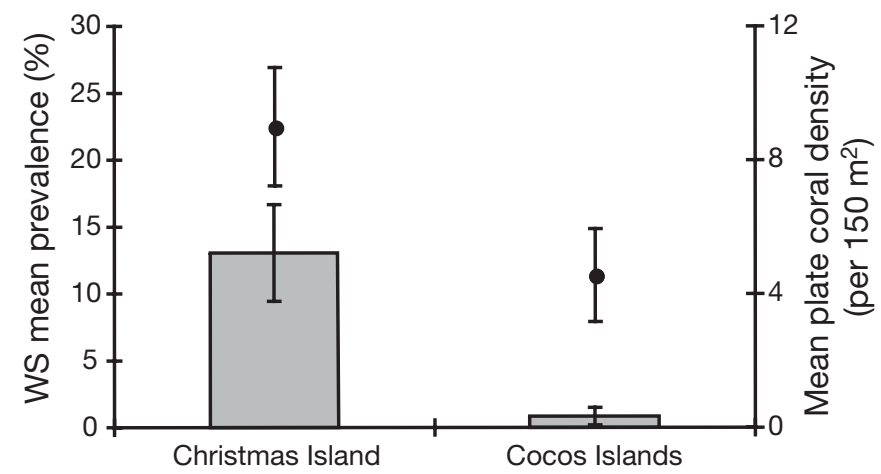

Fig. 2. Acropora plate corals. Mean percent prevalence $( \pm \mathrm{SE})$ of white syndrome (WS) in plate corals (bars) per transect for Christmas Island (30 transects) and the Cocos Islands (27 transects). Mean density $( \pm \mathrm{SE})$ of plate corals (per $\left.150 \mathrm{~m}^{2}\right)$ is presented as dots above bars 


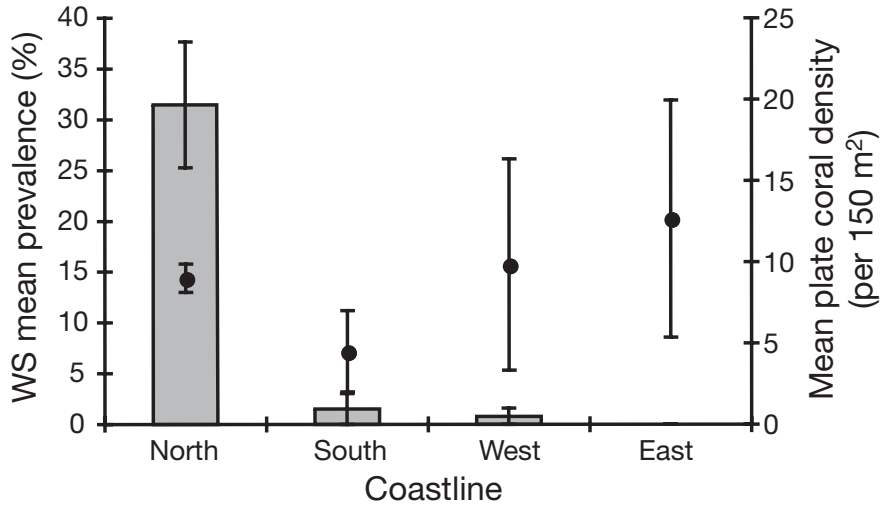

Fig. 3. Acropora plate corals. Mean percent prevalence $( \pm \mathrm{SE})$ of white syndrome (WS) in plate coral colonies (bars) and mean density $\left( \pm \mathrm{SE}\right.$ ) of plate corals (per $\left.150 \mathrm{~m}^{2}\right)$ (dots) on the 4 coastlines of Christmas Island. Two sites were surveyed per coastline, except for the north coast, where 4 sites were surveyed

\section{Depth patterns}

The relationship between WS prevalence and depth was only examined at the 4 north coast sites at Christmas Island, because this is where the majority of WS was observed. The mean percentage of Acropora plate corals with WS was significantly greater in shallow $(31.5 \pm 6.2 \%)$ than deeper water $(6.7 \pm 1.7 \%)$ (ANOVA, $F_{1,6}=14.87, \mathrm{p}<0.01$; Fig. 5). There was no significant difference between shallow and deeper waters in the mean percent Acropora plate coral cover (ANOVA, $F_{1,6}=1.66, \mathrm{p}=0.25$ ) or in the mean number of Acropora plate coral colonies (ANOVA, $F_{1,6}=0.53, \mathrm{p}=0.49$ ).

\section{DISCUSSION}

The white diseases in the Caribbean and those that comprise WS in the Pacific Ocean have been among the most destructive diseases on coral reefs and are increasing in prevalence (Green \& Bruckner 2000, Willis et al. 2004). The present study confirms that WS is also impacting corals reefs in the Indian Ocean. The prevalence of WS at Christmas and Cocos Islands was found to be highest in Acropora plate corals, vary across 3 spatial scales (island, exposure and depth) and correlate positively with host density.

WS in the Pacific Ocean and Red Sea is found in a range of coral taxa (Antonius 1985, Sutherland et al. 2004, Willis et al. 2004, Dalton \& Smith 2006), many of which were present at Christmas and Cocos Islands. In the present study, however, WS was found almost exclusively in Acropora plate corals, which indicates that the causative agent(s) responsible is host specific.

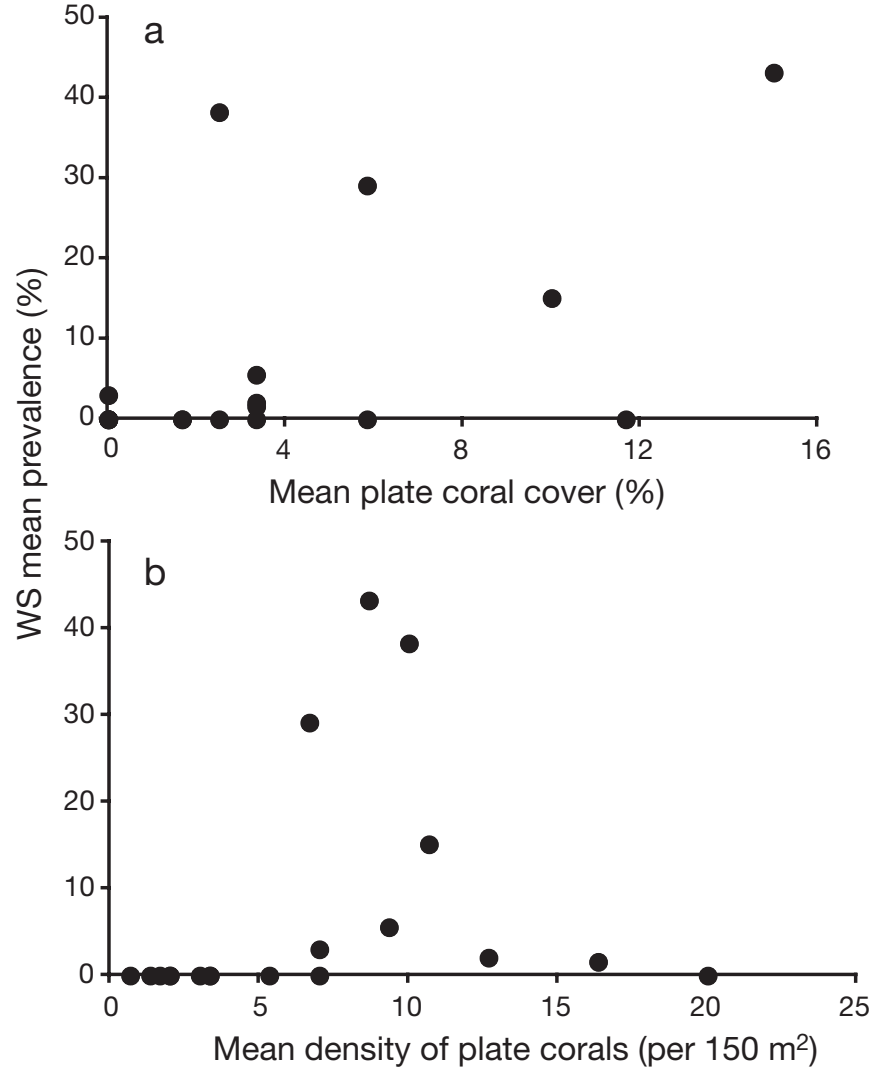

Fig. 4. Acropora plate corals. Relationship between the mean percentage of plate corals with white syndrome (WS) and (a) the percentage cover of plate corals and (b) the mean number $\left(\right.$ per $150 \mathrm{~m}^{2}$ ) of plate corals for $5 \mathrm{~m}$ depth surveys at 19 sites at Christmas and Cocos Islands

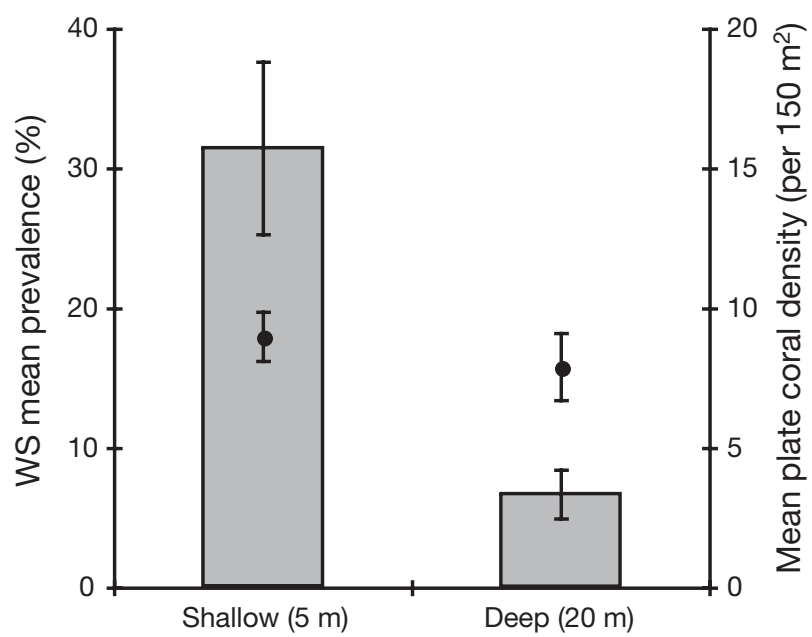

Fig. 5. Acropora plate corals. Mean prevalence $(\%, \pm \mathrm{SE})$ of white syndrome (WS) in plate coral colonies (bars) and mean density $\left( \pm \mathrm{SE}\right.$ ) of plate corals (per $\left.150 \mathrm{~m}^{2}\right)$ (dots) in shallow $(5 \mathrm{~m})$ and deep $(20 \mathrm{~m})$ water at 4 sites on the north coast of Christmas Island 
A similar scenario has been reported on the southern Great Barrier Reef, where the same species of Acropora plate corals (A. clathrata, A. cytherea and $A$. hyacinthus) were affected by 'acroporid white syndrome' in the same manner as observed here (Roff et al. 2006, 2008). The high prevalence of WS in Acropora plate corals conforms with the hypothesis that 'faster growing corals may have decreased disease resistance' (Willis et al. 2004). However, this does not explain why WS was lacking in other fast-growing corals (e.g. pocilloporids, branching and corymbose acroporids). Although the causative agent(s) appears to be specific to Acropora plate corals, the number of coral species affected by disease could increase with time after the initial outbreak (Richardson et al. 1998, Porter et al. 2001, Sutherland et al. 2004), or it is also possible that the limited number of taxa affected at Christmas and Cocos Islands may be due to the fact that this study took place during the initial outbreak.

Although direct comparisons between this and other studies are difficult without knowing the exact causative agent(s) responsible for WS, the data presented here indicate the extent of coral disease on reefs in the Indian Ocean. The prevalence of WS in Acropora plate corals at Christmas Island sites was high (mean $=13 \%$, range $=0$ to $43 \%$ ) compared to in the Pacific Ocean (Willis et al. 2004, Dalton \& Smith 2006), but generally lower than the prevalence of white diseases reported from the Caribbean (Richardson et al. 1998, Green \& Bruckner 2000, Sutherland et al. 2004). WS prevalence at the Cocos Islands was relatively low $($ mean $=0.85 \%$ ). The large variation in WS prevalence in Acropora plate corals between Christmas Island and the Cocos Islands is not unexpected because prevalence of WS and white diseases varies considerably between locations in the Pacific Ocean (Willis et al. 2004) and in the Caribbean (Green \& Bruckner 2000, Sutherland et al. 2004). Why WS prevalence at the Cocos Islands has not reached the levels observed at Christmas Island illustrates the high spatial variability of disease prevalence (Green \& Bruckner 2000, Sutherland et al. 2004, Willis et al. 2004), and further investigations are warranted to identify the environmental conditions that have facilitated the high prevalence of coral disease on certain reefs.

The prevalence of WS in Acropora plate corals at Christmas Island also varied between different sides of the island (i.e. exposure) and between depths. WS was most prevalent in the shallows on the north coast, and this tended to coincide with higher densities of host corals (discussed below). Interestingly, WS prevalence was higher in shallow water (5 m) compared to deeper water $(20 \mathrm{~m})$, even though host densities were similar between depths. A plausible explanation is that envi- ronmental conditions in shallow water (such as greater light intensity or higher water temperatures) promote the occurrence of WS. The relationship between WS prevalence and depth has not been examined elsewhere, but black band disease can be more common in the shallows (Kuta \& Richardson 2002). If WS is only common in shallow water, then corals whose distributions extend into deeper waters may be buffered from the full effects of WS.

Both high hard coral cover and high host density have been hypothesised to be important factors in the prevalence of some coral diseases (Willis et al. 2004, Bruno et al. 2007). For WS on the Great Barrier Reef, outbreaks appear to be dependent on hard coral cover being above a threshold level (>50\%) (Bruno et al. 2007). In the present study, no relationship was found between hard coral cover and WS prevalence. However, there was a positive relationship between WS prevalence and the number and cover of host corals, indicating a role of host density in WS outbreaks. High host densities reduce the distance between host corals, thereby aiding in the transmission of disease between colonies. Bacterial pathogens involved in WS in the Pacific Ocean can pass through the water column and infect a new host (Sussman et al. 2008). The causative agent(s) responsible for WS at Christmas and Cocos Islands and its infectivity is unknown. However, the corals affected by WS appeared to be closely aggregated at the study sites, and this suggests that the causative agent(s) may also be contagious at Christmas Island. If coral disease outbreaks increase as predicted (Harvell et al. 2002) and are facilitated by high host densities, not only will community structure change (Aronson \& Precht 2001, Sutherland et al. 2004), but there may also be a shift towards a more uniform spatial distribution of susceptible corals.

The occurrence of WS at Christmas and Cocos Islands demonstrates that coral diseases can become established on isolated and near-pristine coral reefs. In other regions, coral diseases (including WS) have impacted, and may even be more prevalent, on remote and pristine corals reefs (Willis et al. 2004, Aeby 2005, Bruckner \& Bruckner 2006, Miller \& Williams 2007, Sussman et al. 2008, Williams et al. 2008). The overall impact of disease is likely to be even greater on remote reefs, because the coral populations on these reefs receive very little input of larvae from other locations (Ayre \& Hughes 2004), which limits the recovery of isolated coral reefs following disturbance events (Graham et al. 2006). Not only is recovery likely to be slower at Christmas and Cocos Islands, but the diversity and prevalence of coral diseases may increase in the future. Increasing sea temperatures are expected to promote an increase in disease (Willis et al. 2004), especially for WS (Bruno et al. 2007), and, in the Indian 
Ocean, these increases in sea temperature are expected to be greatest for latitudes from 10 to $15^{\circ}$ south (Sheppard 2003), which includes Christmas and Cocos Islands.

In summary, the present study found that WS prevalence was host specific, spatially variable and positively correlated with host density. Some of the patterns in WS prevalence observed at Christmas and Cocos Islands differ from the patterns recorded at other locations. Additional studies from other Indian Ocean locations are therefore required to establish regional and global patterns in disease prevalence and distribution. Nonetheless, the present study has revealed that coral disease is established, and can become prevalent, on remote and relatively pristine coral reefs in the Indian Ocean. The loss of Acropora plate corals due to WS will not only affect coral community structure, but also other reef organisms that rely on this habitat-forming coral for shelter or food.

Acknowledgements. The authors are grateful for the logistical and financial support provided by Envirofund Australia Natural Heritage Trust, Parks Australia North and Wet ' $n$ ' Dry Adventures. Thanks to C. Banner, G. Christie, J. Gilligan, T. Hamanaka, C. McDonald, J. Neilson and M. Orchard for their valuable field assistance. Constructive comments from B. Willis helped improve an earlier version of the manuscript.

\section{LITERATURE CITED}

Aeby GS (2005) Outbreak of coral disease in the northwestern Hawaiian Islands. Coral Reefs 24:481

> Antonius A (1985) Coral disease in the Indo-Pacific: a first recording. PSZN I: Mar Ecol 6:197-218

Antonius A, Afonso-Carillo J (2001) Pneophyllum conicum killing reef-corals in Mauritius: A new Indo-Pacific syndrome? Bull Mar Sci 69:613-618

Aronson RB, Precht WF (2001) White-band disease and the changing face of Caribbean coral reefs. Hydrobiologia 460:25-38

- Ayre DJ, Hughes TP (2004) Climate change, genotypic diversity and gene flow in reef-building corals. Ecol Lett 7 : $273-278$

Ben-Haim Y, Rosenberg E (2002) A novel Vibrio sp. pathogen of the coral Pocillopora damicornis. Mar Biol 141:47-55

Bruckner AW, Bruckner RJ (1997) Outbreak of coral disease in Puerto Rico. Coral Reefs 16:260

Bruckner AW, Bruckner RJ (2006) Consequences of yellow band disease (YBD) on Montastraea annularis (species complex) populations on remote reefs off Mona Island, Puerto Rico. Dis Aquat Org 69:67-73

Bruckner AW, Bruckner RJ, Williams EH (1997) Spread of a black-band disease epizootic through the coral reef system in St. Ann's Bay, Jamaica. Bull Mar Sci 61:919-928

Bruno JF, Selig ER (2007) Regional decline of coral cover in the Indo-Pacific: timing, extent, and subregional comparisons. PLoS ONE 2:e711, doi:10.1371/journal.pone. 0000711

> Bruno JF, Selig ER, Casey KS, Page CA and others (2007) Thermal stress and coral cover as drivers of coral disease outbreaks. PLoS Biol 5:e124, doi:10.1371/journal.pbio. 0050124
Coles SL (1994) Extensive coral disease outbreak at Fahl Island, Gulf of Oman, Indian Ocean. Coral Reefs 13:242

Coles SL, Seapy DG (1998) Ultra-violet absorbing compounds and tumorous growths on acroporid corals from Bandar Khayran, Gulf of Oman, Indian Ocean. Coral Reefs 17: 195-198

> Dalton SJ, Smith SDA (2006) Coral disease dynamics at a subtropical location, Solitary Islands Marine Park, eastern Australia. Coral Reefs 25:37-45

Done TJ, Marsh L (1988) Reef-building corals. In: Berry PF (ed) Survey of the marine fauna of Christmas Island, Indian Ocean. Report to Australian National Parks and Wildlife Service, Christmas Island, p 29-32

> Goreau TJ, McClanahan TR, Hayes R, Strong A (2000) Conservation of coral reefs after the 1998 global bleaching event. Conserv Biol 14:5-15

Graham NAJ, Wilson SK, Jennings S, Polunin NVC, Bijoux JP (2006) Dynamic fragility of oceanic coral reef ecosystems. Proc Natl Acad Sci USA 103:8425-8429

Green E, Bruckner A (2000) The significance of coral disease epizootiology for coral reef conservation. Biol Conserv 96:347-361

> Harvell CD, Kim K, Burkholder J, Colwell RR and others (1999) Emerging marine diseases - climate links and anthropogenic factors. Science 285:1505-1510

Harvell CD, Mitchell CE, Ward JR, Altizer S, Dobson AP, Ostfeld RS, Samuel MD (2002) Climate warming and disease risk for terrestrial and marine biota. Science 296: $2158-2162$

Kuta KG, Richardson LL (1996) Abundance and distribution of black band disease on coral reefs in the northern Florida Keys. Coral Reefs 15:219-223

Kuta KG, Richardson LL (2002) Ecological aspects of black band disease of corals: relationships between disease incidence and environmental factors. Coral Reefs 21:393-398

McClanahan TR, McLaughlin SM, Davy JE, Wilson WH, Peters EC, Price KL, Maina J (2004) Observations of a new source of coral mortality along the Kenyan coast. Hydrobiologia 530/531:469-479

Miller MW, Williams DE (2007) Coral disease outbreak at Navassa, a remote Caribbean island. Coral Reefs 26: 97-101

Patterson KL, Porter JW, Ritchie KB, Polson SW and others (2002) The etiology of white pox, a lethal disease of the Caribbean elkhorn coral, Acropora palmata. Proc Natl Acad Sci USA 99:8725-8730

Porter J, Dustan P, Jaap W, Patterson KL and others (2001) Patterns of spread of coral disease in the Florida Keys. Hydrobiologia 460:1-24

Ravindran J, Raghukumar C (2002) Pink line syndrome (PLS) in the scleractinian coral Porites lutea. Coral Reefs 21:252

> Richardson LL (1998) Coral diseases: What is really known? Trends Ecol Evol 13:438-443

> Richardson LL, Goldberg WM, Kuta KG, Aronson RB and others (1998) Florida's mystery coral-killer identified. Nature 392:557-558

Riegl B (2002) Effects of the 1996 and 1998 positive sea-surface temperature anomalies on corals, coral diseases, and fish in the Arabian Gulf (Dubai, UAE). Mar Biol 140:29-40

Roff G, Hoegh-Guldberg O, Fine M (2006) Intra-colonial response to acroporid 'white syndrome' lesions in tabular Acropora spp. (Scleractinia). Coral Reefs 25:255-264

> Roff G, Kvennefors ECE, Ulstrup KE, Fine M, Hoegh-Guldberg O (2008) Coral disease physiology: the impact of acroporid white syndrome on Symbiodinium. Coral Reefs $27: 373-377$

Sheppard CRC (2003) Predicted recurrences of mass coral 
mortality in the Indian Ocean. Nature 425:294-297

Smith LD, Gilmour JP, Heyward AJ (2008) Resilience of coral communities following catastrophic mass-bleaching. Coral Reefs 27:197-205

Sussman M, Willis BL, Victor S, Bourne DG (2008) Coral pathogens identified for white syndrome (WS) epizootics in the Indo-Pacific. PLoS ONE 3:e2393, doi:10.1371/ journal.pone.0002393

Sutherland KP, Porter JW, Torres C (2004) Disease and immunity in Caribbean and Indo-Pacific zooxanthellate corals. Mar Ecol Prog Ser 266:273-302

Veron JEN (1986) Corals of Australia and the Indo-Pacific.

Editorial responsibility: John Austin,

Oldendorf/Luhe, Germany
University of Hawaii Press, Honolulu, HI

Veron JEN (1994) Hermatypic corals of Cocos (Keeling) Islands: a summary. Atoll Res Bull 409:1-21

> Williams GJ, Davy SK, Aeby GS (2008) Coral disease at Palmyra Atoll, a remote reef system in the Central Pacific. Coral Reefs 27:207

Willis BL, Page CA, Dinsdale EA (2004) Coral disease on the Great Barrier Reef. In: Rosenberg E, Loya Y (eds) Coral disease and health. Springer, Berlin, p 69-104

Work TM, Aeby GS (2006) Systematically describing gross lesions in corals. Dis Aquat Org 70:155-160

Zar JH (1999) Biostatistical analysis. Prentice-Hall, London

Submitted: August 6, 2009; Accepted: November 13, 2009

Proofs received from author(s): February 17, 2010 